Wilfrid Laurier University

Scholars Commons @ Laurier

3-1-2009

\title{
Standardizing and Disseminating Knowledge: The Role of the OECD in Global Governance
}

Rianne Mahon

Wilfrid Laurier University, rmahon@wlu.ca

Stephen McBride

Simon Fraser University

Follow this and additional works at: https://scholars.wlu.ca/poli_faculty

\section{Recommended Citation}

Mahon, Rianne and McBride, Stephen, "Standardizing and Disseminating Knowledge: The Role of the OECD in Global Governance" (2009). Political Science Faculty Publications. 12.

https://scholars.wlu.ca/poli_faculty/12

This Article is brought to you for free and open access by the Political Science at Scholars Commons @ Laurier. It has been accepted for inclusion in Political Science Faculty Publications by an authorized administrator of Scholars Commons@ Laurier. For more information, please contact scholarscommons@wlu.ca. 


\title{
Standardizing and disseminating knowledge: the role of the OECD in global governance
}

\author{
RIANNE MAHON $^{1}$ AND STEPHEN MCBRIDE ${ }^{2}$ \\ ${ }^{1}$ Institute of Political Economy, Carleton University, Ottawa, Ontario, Canada \\ ${ }^{2}$ Department of Political Science, Simon Fraser University, Burnaby, British Columbia, Canada
}

\begin{abstract}
If 'knowledge is power', it is unsurprising that the production, legitimation, and application of social scientific knowledge, not least that which was designed to harness social organization to economic growth, is a potentially contentious process. Coping with, adapting to, or attempting to shape globalization has emerged as a central concern of policy-makers who are, therefore, interested in knowledge to assist their managerial activities. Thus, an organization that can create, synthesize, legitimate, and disseminate useful knowledge can play a significant role in the emerging global governance system. The OECD operates as one important site for the construction, standardization, and dissemination of transnational policy ideas. OECD staff conducts research and produces a range of background studies and reports, drawing on disciplinary knowledge (typically economics) supplemented by their 'organizational discourses'. This paper probes the contested nature of knowledge production and attempts to evaluate the impact of the OECD's efforts to produce globally applicable policy advice. Particular attention is paid to important initiatives in the labour market and social policy fields - the Jobs Study and Babies and Bosses.
\end{abstract}

Keywords: global governance; OECD; neo-liberalism

\section{Introduction}

Although nation states still formulate policies, they do so in the context of an increasingly dense web of transnational networks, operating at different scales, with different, often overlapping mandates. International organizations such as the OECD function as important nodes in these networks, which, taken as a whole, constitute an uneven, incomplete, and contested system of transnational governance. The OECD is a little studied international organization that has been described in various terms: 'rich man's club', international think tank or even 'shared state apparatus' (Dostal, 2004). Formed in the heyday of the Keynesian-welfare state, ${ }^{1}$ the OECD initially

\footnotetext{
* Email: prmahon@rogers.com

1 The OECD was formed out of the Organization for European Economic Cooperation (OEEC) established in the immediate postwar period to aid in the reconstruction and integration of Western Europe.
} 
emphasized the coordination of members' policies but later, this gave way to a focus on establishing 'best practices' (Wolfe, 2008). As the postwar order began to unravel, the OECD altered its horizons geo-politically through the expansion of its membership, initially including Japan, Australia, and New Zealand, but later moving to admit former members of the Soviet bloc and a leading 'Asian tiger' (South Korea). Although it has always played a role in coordinating its members' development assistance programmes, more recently the OECD has intensified its outreach activities, especially to the major economies of Asia and Latin America. The current Secretary-General aims to make the OECD a 'globalization hub'. Accordingly, at the 2007 meeting of the Council of Ministers, the OECD extended an invitation to Chile, Estonia, Israel, Russia, and Slovenia, while recommending increased 'engagement' with Brazil, China, India, Indonesia, and South Africa.

The OECD deserves more attention than it normally receives in the analyses of transnational governance. To be sure, in contrast with the International Monetary Fund (IMF), the World Trade Organization (WTO), and the World Bank, the OECD lacks the power to enforce compliance with its decisions. Yet, it is much less concerned with establishing binding obligations than it is with influencing the direction of policy, in ways that may in the future become binding on states, but not necessarily through the OECD itself. The OECD thus operates as an important site for the construction and dissemination of transnational research and policy ideas embracing a wide range of contemporary issues. Such ideas play an important role in contemporary transnational governance. In the broadest sense, transnational norms identify what a modern state 'is' and thus sanction appropriate modes of internal and external conduct (Porter and Webb, 2008). In policy terms, the ideas sanctioned by international organizations help to identify problems and to map out the range of 'best practice' solutions. The first two sections of this article explore the OECD's meditative and inquisitive functions (Jacobsson, 2006), highlighting their important contribution to the increasingly dense webs of transnational governance.

The OECD has proved to be flexible in its role as creator, purveyor, and legitimator of ideas, adding and shedding functions as the times and new challenges required. In doing so, it has shifted its position, both reflecting and contributing to larger ideological shifts. Although the OECD originally helped to consolidate the norms associated with the postwar settlement (Keynesian welfare states committed to the liberalization of trade and capital flows), in the late 1970s, it began to foster the spread of neo-liberal solutions.

The change of paradigm meant recasting the goals and contents of both economic and social policies, a process that displaced the Keynesian compromise between economic and social priorities. Such a shift could be expected to reveal differences between and within member nations, rooted in social constituencies and bureaucratic agencies, and within the OECD itself. Moreover, such tensions alerted us to the possibility of ongoing changes in the OECD's thinking, either within or beyond the parameters of the established paradigm. In the third section, 
therefore, we explore these ideological shifts, focusing on two cases that illustrate these differences and serve to generate hypotheses for further research. The first was the 'Jobs Strategy', which single-mindedly pushed a form of neo-liberal flexibilization that undermined the workers' rights. In the early 1990s, the OECD also helped to disseminate the critique of the welfare state as 'burden'. More recently, however, its Directorate for Employment, Labour, and Social Affairs (DELSA) has argued for social policies in support of activation. This policy turn, which, following Craig and Porter (2004), we label 'inclusive liberalism', has a marked gender and generational dimension, focused as it is on promoting women's labour market participation and investing in youth and children. Accordingly, the second case selected is 'Babies and Bosses', an important study of measures to promote the reconciliation of work and family life, launched in 2001, with its final report released in 2007 .

\section{Beyond methodological nationalism: the growth of transnational governance}

In international relations and policy studies, as in much of modern social science, ${ }^{2}$ the dominant approaches have long been rooted in a 'methodological nationalism' - the assumption that 'all social relations are organized at a national scale or are undergoing processes of nationalization' (Brenner, 2004: 28). However, policy studies have increasingly come to recognize the importance of inter- and transnational policy transfer and policy learning. The increased incidence of policy transfer is seen partially as a product of advances in information communication technologies' ability to diffuse information rapidly across time and space, and partially as a consequence of the increasing coordination of policy through international arenas. The policy transfer literature draws attention to the ways in which seemingly closed national policy routines can be 'disrupted' by the policy prescriptions of inter- and supra-national organizations, as well as by the expertise supplied by transnational consultants. In some accounts, lesson drawing is considered a rational, voluntary activity. There is also the important question of the extent to which transfer is always 'voluntary' or even necessarily 'rational' (James and Lodge, 2003).

The twentieth century witnessed the proliferation of international organizations, and it is increasingly recognized that these are more than mere 'empty shells or impersonal policy machinery to be manipulated by other actors' (Barnett and Finnemore, 1999: 704). As a result, interest has grown in transnational (Djelic and Sahlin-Andersson, 2006a, b) governance. The term 'transnational' captures the complex patchwork of networks, operating at variable scales, which together comprise the contemporary system. As Robert Cox (2005: 149) argued, 'The old state system is resolving itself into a complex of political-economic

\footnotetext{
${ }^{2}$ Some might argue that the 'world systems' approach escaped such methodological nationalism, yet the world as imagined by these theorists was still a relatively simple one, composed of the said 'world system' and core and peripheral states.
} 
entities: micro-regions, traditional states and macro-regions with institutions of greater or lesser functional scope and formal authority'. In other words, transnational networks, whether supra-national structures such as the European Union or the much more limited North American Free Trade Agreement, define a new porous and variable territoriality, (macro)regional in scope. At the same time, cities and other sub-national governments have gained a new international visibility as centres of important 'micro-regions' or as 'global cities'. Nation states still matter, but their boundaries are being increasingly recognized as permeable.

The choice of the word 'governance' is also deliberate. It refers to 'governance without government' (Cox's famous 'nébuleuse'), that is, the development, at multiple scales, of a variety of mechanisms of regulation, operating in the absence of an overarching political authority. The absence of formal hierarchy, in turn, suggests the utilization of 'soft' as well as 'hard' (i.e., formal laws and directives) regulation. 'Epistemic communities' (Haas, 1992) or networks of knowledgebased experts - sometimes operating through international organizations, other times through informal networks - are engaged in identifying state interests and/ or common problems to be tackled in a coordinated manner. In addition, 'social forces' (Cox, 1987) contribute to the construction/transformation of structures of transnational governance.

Thus, in addition to classic regulation, with formal laws or directives backed by penalties for violation, the emergent system of transnational governance includes inquisitive and meditative modes of regulation (Jacobsson, 2006), in which the OECD is heavily involved. Inquisitive regulation involves surveillance or monitoring the actions of states. Accordingly, practices such as establishing benchmarks and the organization of peer review processes entail the auditing, comparison, and ranking of state practices. The OECD has been an innovator in developing such international peer review exercises. Formal international organizations play an important role in inquisitorial activities, and their activities are supplemented by the work of quasiformal networks such as the G8, and private actors such as international bond rating agencies (see Sinclair, 2005) and international cartels. In many cases, the OECD acts as its own inquisitor, in which members' performance is gauged against the best practices and recommendations that emerge from the organization's meditative activities.

Meditative activities 'are mainly framed as discussions among experts about what is the best way or ways of doing something' (Jacobsson, 2006: 208). It is from such 'meditative' fora that hard regulations frequently emerge and from which the standards or 'benchmarks' that constitute the stuff of inquisitions are derived. The meditative function can be viewed as contributing to the construction of broad paradigms (see Hall, 1993) that, once adopted, shape subsequent policy choices and their implementation. As Jacobsson and Sundstrom (2007) suggest, international organizations are 'important actors in the making of these discourses. They act as "hosts", making sure that representatives of states not only read the same documents, but also meet recurrently to discuss the various issues; 
they have a kind of meditative function'. Indeed, the role of international organizations may be more active than that which is suggested by the role of 'hosts', disseminating documents, and convening meetings to discuss them and draw out the implications for action. Certainly, in the OECD's case, many of the 'documents to be read' are products of the OECD's formidable research capacity. The OECD employs a substantial staff of in-house experts and from this base organizes transnational networks of researchers in numerous fields.

This does not mean that nation states have disappeared. They remain as key decision points, though they make policy in a context increasingly shaped by multiple and overlapping transnational networks. Although some forms of policy transfer entail direct or indirect measures of coercion, transnational governance, especially as it is applied to advanced capitalist countries, more typically takes the form of policy learning. It should not, however, be assumed that such learning is merely a rote exercise (though it may be), through which policy and programme models are imported from elsewhere and applied in a procrustean manner. Rather, as Djelic and Sahlin-Andersson (2006a: 15-16) suggest, 'the travel of ideas is an active process and ideas are shaped and translated differently in different settings. Carriers are active in structuring flows and patterns of diffusion but they are also translating the ideas they mediate, reflecting in the process their own projects and interests'.

The emphasis on 'soft' instruments of governance and transnational networks does not mean the absence of power and contestation. Clearly, meditative activities channelled through international organizations involve the power to classify, fix meanings, and diffuse norms (Barnett and Finnemore, 1999: 711), whereas inquisitive processes, such as peer reviews, entail the exercise of the power of surveillance/monitoring, creating pressures on states to conform to new standards and practices. The dominant norms and ideas are decidedly 'Western', that is, individual human rights, modern bureaucracy as the paramount form of political organization (Finnemore, 1996: 332), and also liberal economic theory and its definition of efficient economic organization (market economies). The terminology of neo-Gramscians may be different - bourgeois individualism, capitalist relations of production - but it points in the same direction. However, power needs to be understood in relational terms. The existence of deep tensions in globalized Western culture leaves ample room for contestation over 'the logic of appropriateness'. It is important, therefore, to recognize the implications such contestation holds for international organizations.

\section{The OECD in the emerging structure of transnational governance}

The OECD's work does not focus on classic foreign policy issues, nor does it possess the budgetary or sanctioning powers enjoyed by the main economic international organizations, the IMF and the World Bank. Unlike the International Labour Organization (ILO), whose conventions have to be submitted to parliaments (Armingeon, 2004: 227), governments can merely choose to ignore 
the OECD's advice. Nonetheless, the OECD did play an instrumental role in developing the 'inquisitive' and 'meditative' modes of (Western) governance in the postwar period. Furthermore, the OECD Secretariat ${ }^{3}$ enjoys a certain autonomy $v i s$-à-vis both transnational social forces and member states, including the most powerful (the US) among them. That autonomy, however, is only relative.

Although the IMF and the World Bank were charged with the provision of short-term loans to relieve balance of payment difficulties and longer term loans for 'development', the OECD initially focused on surveillance of economic policies and outcomes in the North Atlantic, with an eye to harmonization. As Cox (1986: 231) noted, 'such procedures began with the mutual criticism of reconstruction plans in Western European countries (the US condition for Marshall Plan funds), continued with the development of annual review procedure in NATO... and became an acquired habit of mutual consultation and mutual review of national policies (through the OECD and other agencies)'. In fact, it was the OECD's predecessor, the OEEC, which was created to manage this process. As Wolfe (2008) argues, the OEEC was unable to play the role - allocation of Marshall Plan aid - initially envisaged by the Americans. From 1948 to 1958, however, the OEEC successfully ${ }^{4}$ worked to remove quantitative trade restrictions in Europe. Moreover, it helped lay the foundations for the European Economic Community and the European Free Trade Association (Salzman and Terracino, 2006: 315), whereas the European Payments Union it formed worked to secure currency convertibility in Western Europe (Porter and Webb, 2008: 2).

Formed in 1961, the OECD went on to develop and refine techniques for the surveillance of member countries' economic performance, and the assessment of their policies across a growing range of fields. Article 3 of its convention committed member states 'to furnish the Organization with the information necessary for the accomplishment of its tasks'. This commitment formed the basis for the routine collection of statistics from member (and, increasingly, nonmember) countries, and their assembly into regular reports such as the Economic Outlook (Economics Department) or 'Society at a Glance', produced by the DELSA. Such activities are routine, however, only in the sense that they form one of the organization's regular, ongoing activities. The OECD Secretariat plays an active role here, identifying 'appropriate' indicators and developing common ways of measuring in order to permit cross-national comparison and ranking. The 'league tables', thus constructed, make visible each country's performance relative to that of its peers, putting pressure on 'laggards' to improve their performance.

\footnotetext{
3 The OECD has a staff of about 2000. Approximately 800 of these are professionals, 40 percent of whom are economists. Initially, the intent was to recruit middle and higher level civil servants on a 5 -year rotation from the member states, but Salzman and Terracino suggest that 'many in the secretariat make their careers at the OECD' (2006: 324).

${ }^{4}$ By 1961 , only $5 \%$ of European trade - mainly in the area of agriculture - was subject to quantitative restrictions (Sullivan, 1997).
} 
Sometimes inquisition involves more elaborate activities. For instance, the PISA student performance assessments require participating countries to administer a specific examination procedure, designed by a network of experts, coordinated by the Directorate for Education. The biennial country surveys produced by the Economics Department involve the ongoing engagement of OECD staff with their national counterparts. As this methodology is applied, more or less systematically, in other OECD studies, it is worth considering in greater detail.

The production of a country report begins with the design of a questionnaire, prepared by the country desk in the Economics Department of the Secretariat. The questions posed 'direct their attention to a set of problem areas that the OECD finds interesting. The questionnaire also provides a vocabulary introduced by the OECD, which conceptualizes the problems and limits the margin of manoeuvre for member countries' (Noaksson and Jacobsson, 2003: 32). The country under review is obliged to answer the questionnaire, and thus to enter into the mental framework established by the Secretariat. The next step is a visit by the OECD mission, which involves meetings with key ministries, the central bank, appropriate domestic experts, and relevant civil society representatives. In addition, it enables the OECD team to establish/reinforce links with like-minded domestic officials, creating a potential basis of support for the recommendations to be contained in the final report. ${ }^{5}$

Up to this point, the process is led by the Department, which engages in a 'bilateral' dialogue with its member country counterparts, especially the key economic ministry (usually the department of finance). The completion of the next draft launches the peer review process, drawing-in representatives of other member states. The draft report, which 'can be quite explicit with pointed recommendations and detailed case studies' (Salzman and Terracino, 2006: 319), is distributed 4 weeks in advance of the meeting of the Economic Development and Review Committee (EDRC). Two peer reviewers are appointed to lead the discussions, which can involve quite sharp debates with the country under review seeking to blunt criticism, especially in domestically sensitive areas. The whole debate takes place under the rule of 'derestriction': that is, no publication can be released until all - both the country under review and its peer-critics - agree (Salzman and Terracino, 2006: 319). ${ }^{6}$ The final report released to the public, thus, typically represents a compromise, which the Secretariat often plays an active part in reaching (Noaksson and Jacobsson, 2003).

The production of the country reviews, thus, constitutes a classic example of the inquisitive mode of governance in operation. A similar procedure is followed

\footnotetext{
5 There is often a second visit, following the production of the interim report, to enable the team to update information and engage in more protracted discussions with national officials (Schäfer, 2006: 74).

${ }^{6}$ Sullivan (1997: 491) suggests that some reports have been held up for months, as the country under inspection tries to persuade staff and fellow committee members to adopt a different tone, or to change prescriptions, whereas Salzman and Terracino suggest that some reports are never published (2006: 319).
} 
by other parts of the OECD Secretariat in conducting other reviews or special thematic studies, such as the regulatory review launched by the Directorate on Governance and Territorial Development (GOV) in 1997 (Lodge, 2005). Just how effective is this process, however, in inducing conformity on the part of the member states?

The Armingeon and Beyeler (2004) volume examines the impact of the OECD country reports on the social policies of its Western European members. Armingeon concludes that the OECD's advice enjoyed 'low efficacity'. Even where there appeared to be a strong link between OECD recommendations and member country policy, such as the UK, there was little evidence that the OECD set the agenda for change. Recent in-depth studies of education reform in Belgium, Hungary, and Portugal, however, show that negative PISA rankings helped to trigger or accelerate the reform process (Bajoni, Berenzi, and Neuman, 2007; Barroso et al., 2007; Delvaux et al., 2007). Certainly, a significant group of countries prospered inspite of not following the OECD Jobs Strategy's prescription for the 'liberalization' of domestic labour markets. Yet, as Grinvalds (2008) suggests, even countries such as Denmark, that refused to tow its line, introduced reforms.

The OECD's main contribution to transnational governance may, however, be its 'meditative' function. Here, its formidable research capacity is brought into play. Its research enables it to highlight certain trends, to identify common problems, and to map out a range of appropriate solutions. This can involve complex technical work, which allows the broadening of the range of statistical surveillance by factoring new data into the equation. ${ }^{7}$ Sometimes, the concepts thus produced facilitate the coordination of member country activities vis-à-vis non-members. Occasionally, practical concepts originating at the OECD migrate into agreements sanctioned by other international organizations. Thus for instance, Sullivan credits the OECD's Environment Directorate with devising the concept of 'polluter pays' (1997). Wolfe (2008) argues that the Trade Directorate and the Trade Committee's work on the concepts of producer and consumer subsidy equivalents, laid the basis for the 'aggregate measure of support' breakthrough at the WTO.

Such 'meditation' does not, however, take place in circumstances equivalent to that of the proverbial 'ivory tower': 'ethnographic studies of international organizations (IOs) describe a world in which organizational goals are strongly shaped by norms of the profession that dominate the bureaucracy and in which interests themselves are varied, often in flux, debated, and worked out through interactions between the staff of the bureaucracy and the world in which they are embedded' (Barnett and Finnemore, 1999: 706). This accurately describes how the OECD performs its meditative function. OECD staff conducts research and produces a range of background studies and reports. In this, they draw on their disciplinary

\footnotetext{
7 One such example is the work behind the new 'SOCX' database, which, inter alia, enables the analysis of the wider field of 'social benefits', including those provided by private institutions. Willem Adema's work has been instrumental here.
} 
knowledge, supplemented by what Dostal (2004: 445) refers to as an 'organizational discourse' - 'claims encapsulating long-term political projects as defined by the organization in question'. The latter reflects the effects of organizational learning. Thus, an ethnographic account of a directorate would map the way key studies and policy documents produce important themes and concepts, which infiltrate and modify its 'pure' disciplinary discourse. As we shall see, the 'Jobs Strategy' became such a key document/learning experience for the Economics Department.

Such learning does not occur purely 'in house' of course. Research directions and priorities are set by the managing committee to which each directorate reports; below this is a myriad of sub-committees, working and expert groups that regularly bring OECD staff into dialogue with national officials and other experts in their field (Salzman and Terracino, 2006: 324). Sahlin-Andersson (2000) has examined the way in which the Public Management Committee (PUMA) of the Governance Directorate helped codify and disseminate the themes of 'new public management', an amalgam of public choice theory, principal-agency theory, and transaction cost economics, given practical significance by the public sector reforms instituted in the Anglo-Saxon countries, especially New Zealand, during the 1980s. She argues that PUMA's actions involved the 'editing out' of countryspecific experience to produce generalizable conclusions.

The OECD's 'policy learning networks' also include representatives of civil society. From the outset, the OECD has been involved in a regular dialogue with the Business Industry Advisory Committee (BIAC) and the Trade Union Advisory Committee (TUAC). ${ }^{8}$ Both regularly consult with the OECD Secretariat and the various committees and working groups. The two associations can also discuss OECD agenda items through the Labour/Management Programme, which is partly financed by the OECD (Salzman and Terracino, 2006: 329). More broadly, although the Committee for Agriculture and the Environmental Directorate have long had relations with civil society groups, the MAI fiasco spurred the OECD to develop greater dialogue with civil society representatives, although this proceeded selectively and unevenly. Thus, although the Agriculture, Environment, and (now) Investment Committees have been actively engaged, the Economic Policy Committee (ECO) remains aloof from such civil society consultations. Yet, as Sullivan suggests, it is ECO - and its highly influential Working Party 3 (WP3) that is in charge of key routines, including the working-out of common policies in advance of the annual G-7 (now G-8) summits (1997: 62). ${ }^{9}$ This suggests that the

8 TUAC's origins date back to the immediate postwar period, when it was created 'to provide advice to the OEEC in its implementation of the Marshall Plan' (Salzman and Terracino, 2006: 327). Mindful of the tide of worker revolts in the aftermath of World War I and fearing the spread of communism, Western leaders were keen to involve unions in postwar reconstruction. BIAC's birth coincides with that of the OECD.

${ }^{9}$ It became eight with the addition of Russia. 
'inner sanctum' - the site where the most important economic policy issues are dealt with - remains relatively insulated from civil society.

What of the OECD's relationship with non-member states? From the outset, the OECD functioned as a key node in the construction of the North Atlantic alliance against the Soviet bloc in Eastern Europe. With the latter's disintegration in the late 1980s, the OECD joined other IOs in facilitating the transition to market economies. According to Sullivan (1997: 45), 'a key element in the program... [was] SIGMA - Support for Improvement of Governance and Management in Central and Eastern European Countries, run jointly by the OECD and the European Union'. Through SIGMA, the Economic Development and Review Committee prepared reports on eastern European countries, 'essentially bringing those nonmember states into the OECD surveillance process' (Williams, 2008). These reports focused on issues of appropriate forms of public sector management for the emerging market economies. In the 1990s, the Czech Republic, Hungary, and Poland were admitted to the OECD, with the Slovak Republic following in 2000. Their admission to the 'club' marked their 'progress' towards the establishment of market economies and liberal democracies.

It is in its relation to the global south that the OECD especially stands out as a 'rich nation's club'. In contrast to UN agencies, the OECD has offered its member states a safe forum to explore common interests of the (capitalist) North vis-à-vis the South. Yet, the states of the global south are not monolithically composed of equally poor countries, a point driven home in the 1980 s by the performance of the Asian tigers. Since 1992, the OECD has permitted the participation of nonmembers in its work, and one of the Asian tigers - South Korea - was admitted to the OECD in $1996,{ }^{10}$ following Mexico, ${ }^{11}$ admitted in 1994, after it became a signatory to the North American Free Trade Agreement with Canada and the United States. The OECD is currently involved in active outreach activities in East Asia, Latin America, and Africa. This raises questions about the effect of the expansion of membership on the institution's attractiveness as a 'rich country's club', offering a safe venue for the development of common strategies vis-à-vis the rest of the world.

Not all OECD's original member states are equal in wealth and power. This raises the question of whether the OECD is and has always operated as a site for the exercise of 'Americanization'. The OECD's predecessor, the OEEC, was certainly established to help implement the US Marshall Plan. Its replacement by the OECD brought the US (and Canada) into what had been a European organization. The OECD's budget is also based on financial contributions that reflect the size of each member's economy. Hence, the US contributes the largest share to

\footnotetext{
${ }^{10}$ See Salzman and Terracino (2006) for an interesting analysis of one of the terms imposed on Korea compliance with international labour standards - and OECD's ineffectiveness in enforcing this.

11 The current Secretary General is a Mexican, Angel Gurria, whom Woodward identifies as a strong proponent of neo-liberalism.
} 
the OECD's budget, followed by Japan. Although the Secretaries General have come from a variety of countries, one of the Deputy Secretary General posts is normally occupied by an American. ${ }^{12}$ More broadly, Dostal (2004) estimated that of the OECD's professional staff of 858, Americans (133) were only exceeded by the French (182). ${ }^{13}$ Many of these are economists, trained in neo-classical economics, a discipline in which the US increasingly sets the standard. ${ }^{14}$ There are also specific instances where American policies clearly set limits to what the OECD could do. Thus for instance, Webb's (2004: 815) analysis of the fate of the OECD's 'harmful tax competition' treaty concluded that 'The Bush Administration's anti-tax ideology had a huge impact on the OECD project even though that ideology found little official support in any other OECD country'.

Nevertheless, unlike the World Bank and the IMF, the OECD's headquarters are in Paris, not in the US. A majority of member states remain European, and Europeans constitute the majority of its professional staff, a situation that enables the addition of social democratic ideas to the policy mix, especially with the victories of Left governments in key European states during the latter half of the 1990s. In addition, there are strong connections between the European Commission and the OECD. The European Union is an active participant in many of its committees and has representation on the Ministerial Council. The two organizations collaborate on various projects, although the OECD's longer research involvement around labour market and social policy issues, and larger staff complement means that it is the Commission that looks to the OECD rather than the reverse. ${ }^{15}$

Perhaps, however, the real question is not which member country(s) dominate(s) the OECD. It is more useful to focus instead on the networks of transnational governance and the concomitant internationalization of the state. Thus, for Cox (2005: 232), one consequence of the internationalization of the state is that 'new axes of influence link international policy networks with the key central agencies of government and big business'. It is principally core ministries, such as finance, that are most strongly linked into dialogue and 'meditation' with the OECD, especially its central components, the Economics Department, and its key committees. Yet, although while national states may have been penetrated by transnational networks, they still remain important sites of deliberation and, ultimately, policy decision. They remain, therefore, more than mere transmission belts for ideas established

12 Initially there were two posts, now there are four, and one of these is occupied by an American.

13 The US was followed by 90 from the UK, with Canada, Germany, Japan, and Italy accounting for between 51 and 62 professional staff each.

${ }^{14}$ In an earlier era, there were more national schools of economics, for example, the Stockholm school, where Gunnar Myrdal and others developed an indigenous version of Keynesian analysis; French, Finnish, and a distinct British school (Joan Robinson and others) (see Hall, 1993). Now the US sets the standard even in the newer developments (neo-institutional economics - North, etc.).

15 DELSA and the Commission began to cooperate on employment in the late 1990s (Noaksson and Jacobsson, 2003) and, since the Lisbon process, on social policy too. More recently, they have been working together on a family database (Email communication with Mark Pearson, 5 April 2007). 
elsewhere. Policy learning may be taking place in an increasingly transnational context, but that learning can involve a creative process in which national states draw their own conclusions from the lessons learned.

\section{Continuities and discontinuities: from Keynes to neo-liberalism and beyond?}

Thus far, we have stressed the central role that ideas play in OECD's contribution to transnational governance, and the processes through which it develops and disseminates these. We have not, however, closely examined the question of what sort of ideas the OECD has developed and supported. Like states in relation to powerful interests in their own societies, the OECD enjoys a relative autonomy in constructing ideas, even if, in general, it tends to reflect the ideological tenor of the times. Thus, until the mid-1970s, the OECD reflected the postwar conventional wisdom of Keynesianism. Thereafter, the organization gradually came to adopt a different policy paradigm, generally referred to as monetarism or neo-liberalism, contemporary renditions of traditional neo-classical economics. Many observers detect some shift in OECD thinking in recent years. How far it has moved from an earlier neo-liberal orthodoxy remains a matter of debate and may, in fact, vary by issue area, as a more detailed discussion of two initiatives - the Jobs Strategy and Babies and Bosses suggests. A comparison of the earlier work conducted by the authors suggested that a discussion of these cases could helpfully identify a degree of ideological variation within the OECD, expressed by different offices within the organization, themselves linked to different actors at the member state level, and occupying policy spaces that are located differently to the central objectives of the OECD. In the concluding section of this article, we specify hypotheses for future research that were generated by the comparison.

The OECD's internal discourse has often been viewed as being dominated by Anglo-American trained professional economists. As such it can be expected to reflect trends in economics, especially as taught in the Anglo-American universities and popularized by think tanks based in those countries (Dostal, 2004: 440, 446). That said, the OECD is not one-dimensional and is not merely a transmission belt for the ideas dominant in economics departments. Different trends within orthodox economics may be used by different agencies within the OECD itself. In part, this may reflect their links with different agencies in member states. Although the Economics Directorate tends to interact closely with national finance ministries, DELSA engages with ministries dealing with labour and social issues. To the extent that these transnational networks draw on different trends within orthodox economics, one might expect to see an 'inclusive' liberalism compared with the hard neo-liberal economics perspective of the Economics Department. In addition, different directorates develop distinct organizational discourses, which are reflected in key documents.

The McCracken report marked the beginning of the hegemony of neo-liberalism within the OECD. Adopting a supply side approach to the labour market, the 
McCracken report's analyses and prescriptions pointed the way to a new orthodoxy, based on removal of rigidities and enhanced flexibility within the labour market (McCracken, 1977: 221-223), themes that would figure prominently in the Jobs Study of the 1990s. Of course, particular member states had already begun to shift away from the OECD's earlier discourse. Nonetheless, the McCracken report formed part of a broader paradigm shift in which the inability of an existing paradigm to explain discordant evidence and advance solutions to problems played a part in its replacement.

A later example of the power of economic orthodoxy is provided by the Jobs Study and Jobs Strategy exercises of the 1990s and early 2000s. The Jobs Study proved an important document, especially for the organizational discourse of the influential Economics Department. To a certain extent, the initial Jobs Study reflected different institutional interests within the OECD, which are themselves reflective of broader interests and theoretical disputes in society. Initiated in response to concerns about unemployment, especially in a number of European member countries, the Jobs Study provided an analysis, which involved several directorates under the lead of the General Secretariat. Although there was some effort to recognize the fact that economic flexibility for employers should be combined with economic security for workers, the document was grounded in a neo-liberal analysis of labour markets on the basis of the concept of a nonaccelerating rate of unemployment (NAIRU) (McBride and Williams, 2001). The significance of this theory is that it locates obstacles to non-inflationary employment growth within the labour market itself, rather than deficiencies in aggregate demand or productive capacity. It therefore provides an economic rationale for deregulated 'flexible' labour markets. Although certainly mainstream by the early 1990s, the doctrine is by no means uncontested within the economics profession (see Sawyer, 2004).

The original document evolved into the Jobs Strategy, for which the economics department assumed sole responsibility (Noaksson and Jacobsson, 2003: 17-18). It typified the department's neo-liberal discourse and was strongly reflected, inter alia, in the biennial country surveys discussed in the earlier section. Moreover, with DELSA no longer closely involved, the desire to balance flexibility with security gave way to a more pronounced focus on deregulation and flexibility in the labour force (Noaksson and Jacobsson, 2003: 47-48).

The contrast between selective, theory-driven approaches on the part of the OECD, emanating from its economics department, and more contextual, interdisciplinary approaches characteristic of other organizations, is traced in a comparison of the Jobs Study and the EU's Employment Strategy. Noaksson and Jacobsson suggest that: 'while the EU attempts to adapt knowledge to fit reality, the OECD attempts to adapt reality to fit existing knowledge' (2003: 10). Similarly, Casey points to the greater influence of social considerations on EU analyses of the labour market: the European strategy reflects greater awareness of the potentially negative outcomes that can result from following through with 
some of its recommendations. Accordingly, it is more willing to counsel caution, and more willing to suggest the need for compensatory actions. That it does so is a corollary of it being influenced by a social model in a way that the OECD strategy is not' (Casey, 2004). This would be one reason for non-compliance with the Jobs Strategy on the part of some countries. The strategy seems to have been perceived as one that was useful for Finance Ministers in pushing for reforms but, where social partners were in a position to resist, unlikely to be implemented.

The fact that there was a significant degree of non-compliance with Jobs Study recommendations, and that those who failed to follow OECD advice often outperformed those who did (McBride and Williams, 2001), raises questions about the OECD's own ability, or at least that of its Economics Department, to engage in policy learning. Eventually, however, the empirical record of the Jobs Strategy did force a partial re-evaluation. In 2003, the Employment and Labour Ministers asked the secretariat to re-assess the entire strategy. This led to the 2006 release of Boosting Jobs and Incomes - Policy Lessons From Reassessing the OECD Jobs Strategy along with supporting studies in the 2006 Employment Outlook. One unresolved issue is whether the change(s) represent a new paradigm, distinct from the neo-liberalism that has characterized OECD policy approaches since the mid-1970s, or whether it represents adjustment, modification, and fine-tuning of that approach, which responds or reacts to criticisms of the neo-liberal model without sacrificing the fundamentals of that approach?

Since 2006, the OECD has formally recognized that there is more than one path to good labour market performance. Yet the re-assessment also involved a new emphasis on ensuring adequate labour supply for the future, rather than improving the employment rate now. As well, the report stressed the need to support the knowledge economy through adult skills, and investment in training that were already pillars of the economic growth platform published in the 2003 OECD Growth Study. Although the 2006 revisions do reflect changes, much of the analysis and policy advice on how to achieve the new goals remains staunchly neo-liberal.

The new recommendations clearly favour a more neo-liberal policy framework, including the familiar litany of removing labour market rigidities, keeping unemployment and social assistance benefits low, keeping minimum wages low, and reducing access to long-term disability and early retirement programmes (OECD, 2006). The proposals also encourage states to remove tax and pension incentives that encourage people to leave the labour market early, while also suggesting that income taxes should be reduced to 'make work pay'. All these measures are promoted as vital to ensuring that labour markets are competitive and provide employment even for low productivity workers. They also act to ensure that the labour market is 'flexible' (in the language of the earlier Jobs Study) for employers. These recommendations thus fit well with the assumptions and 'best practices' put forward by the original Jobs Study and seem to directly attack the underlying structures of the alternative flexicurity approach. 
In other spheres, triggered by the unpopularity of neo-liberalism around the world, electoral results in some key European countries, and the European influence on the Paris-based OECD, the OECD has re-discovered the need for positive social policy, which reflects a turn towards 'inclusive liberalism' (Craig and Porter, 2004). The latter differs from neo-liberalism in its emphasis on investing in people who show that they are willing to take responsibility for their own development, providing 'carrots' rather than sticks within a supply-side approach, providing incentives to encourage men to share parental leave, and a range of other 'positive' measures. However, it shares several important assumptions with neo-liberalism: acceptance of trade and investment liberalization, commitment to non-inflationary growth and fiscal conservatism, a supply-side approach to employability that stresses 'flexibility', and acceptance of inequality 'in the here and now'.

Perhaps the best evidence that the OECD - or at least DELSA, one of its important directorates - is modifying its attachment to neo-liberalism, is in the area of social policy. This is especially apparent with respect to measures to promote the 'reconciliation of work and family life'. In the 1980s, DELSA had joined in the conversion to neo-liberalism, declaring social expenditures a burden at its 1980s conference on 'the crisis of the welfare state' (Deacon, Hulse, and Stubbs, 1997). It began to chart a different course, however, with the publication of New Orientation for Social Policy (1994), in which it declared that reform did not require cuts to social expenditures, but rather the development of 'efficient and effective' social policies designed to address the new social, economic, and political realities. In fact, Jenson suggests that it was the OECD that took the lead in promoting the shift from 'classical' neo-liberalism to what she calls the 'social investment' paradigm (2007: 17). In contrast to the postwar 'social protection' paradigm that focused on sustaining (male breadwinner) incomes in times of unemployment, sickness, or retirement, the new paradigm, which we describe as 'inclusive liberalism', calls for social policies that facilitate the development of capacities (human capital) over the course of life.

The new social policy orientation, with its stress on 'social investment' and 'activation', had an important gender component right from the beginning. The rise in women's labour force participation was welcomed for its contribution to women's 'self-realization' and autonomy, as well as for its economic role. These benefits, however, posed new challenges, notably by creating demand for care work traditionally provided within the home. The ideas laid out in New Orientation were developed through conferences and in-house research, and this was reflected in A Caring World (1999), which accorded well with inclusive liberalism's emphasis on state support for economically active, 'empowered' individuals.

The social policy discourse developed by DELSA in the 1990s provided the theoretical basis for Babies and Bosses, a detailed 13-country comparison of 'family-friendly' policies, launched in 2001. It scrutinized tax and benefit policies to identify disincentives to women's labour market participation, recommending 
the elimination of spousal allowances, and the exemption of lone parents from the obligation to work. Yet it did not only recommend cuts. In fact, it was quite prepared to counsel public support for childcare and parental leave (of appropriate length, so as not to contribute to the destruction of human capital). Moreover, it recognized that it was women whose lives were being changed in the new 'family-friendly' world. Men's patterns had not changed in most of the countries examined. Although initially Babies and Bosses saw little possibility of changing the gender division of labour in the home, by the final volume it had come to recognize that genuinely family-friendly policies had to include measures to change this. Its commitment to greater gender equality is visible in the new family database, which includes items such as pay gaps between full and part time (mainly female) workers, male and female earnings, sectoral/occupational concentration by gender, and the gender distribution of child care leave.

Babies have laid the groundwork for the ongoing evaluation of the member countries' family-friendly policies. Nevertheless, the realization of gender equality, not to mention class equality, will remain limited as long as states are constrained to operate within tight fiscal parameters and as long as flexible labour markets, even of the 'flexicurity' variety accepted in the Revised Job Strategy, are the idea. Thus, although DELSA's social policy discourse can be seen as evidence of a turn to inclusive liberalism, it is the very assumptions that it shares with its neo-liberal counterpart, especially the commitment to flexible labour markets, which limit its progressive character. In other words, it does not challenge the existence of evermore polarized labour markets but only seeks to make it possible for individuals to escape the 'poverty bus'.

\section{Conclusions}

One thread running through this analysis is that the OECD represents an important but under-emphasized node in the growing networks of transnational governance. In fact, it has pioneered the inquisitive and meditative forms that other inter- and supranational organizations have more recently discovered. The studies it conducts not only feed into policy discussions in other international fora, such as the G-8 and WTO, but its reports also infiltrate national debates, often from privileged locations within them, such as Ministries of Finance, where the aura of expertise surrounding the OECD may be used by national and subnational actors who seek to advance the broader neo-liberal agenda. Nevertheless, in times of transition and marked contestation such as these, the OECD is far from monolithic. Different ideological and policy currents may find expression in, and even result in, conflict among different branches of the organization, opening up the possibility that actors seeking alternatives to neo-liberalism may draw on the OECD's prestige for their own purposes.

Just how much does the OECD deviate from the neo-liberal consensus that has predominated in the major IOs such as the IMF and the World Bank since the 
1980s? Clearly, detectable changes are underway at the OECD. Do these reflect the emergence of an alternative paradigm? Certainly, DELSA's 'inclusive liberalism' is distinct from the neo-liberalism that remains dominant within other sections of the OECD, notably its Economics Department. It does not, however, challenge the fundamentals, especially as these concern the drive for flexible labour markets, which has contributed to employment and income polarization in many of the OECD member countries. The revised (2006) Jobs Strategy belatedly accepts that there is another route to 'good' labour market performance and international competitiveness other than that recommended by the original Jobs Study. Nevertheless, the new Jobs Strategy continues to reflect neo-liberal goals and policy instruments, an indication that any change in direction is one of adjustment rather than transformation. That said, it is clear that the OECD provides a forum in which officials from member states, the OECD's own expert staff and, to a certain extent, selected representatives of civil society can actively construct transnational policy ideas. If their deliberations reflect the prevailing paradigm, it is also true, as the Babies and Bosses case makes clear, that the construction of alternatives and adjustments is also represented within the organization.

We selected the Jobs Strategy and Babies and Bosses for a more detailed analysis for several reasons. First, they show that the OECD is not a monolithic organization. The Jobs Strategy remains largely informed by the tenets of neoliberalism, whereas Babies and Bosses shows some movement towards a more inclusive form of liberalism. Second, the fact that these two examples stand on potential fissures within the OECD enabled us to consider several hypotheses that might figure in future research on that organization. These are: the more central an area to the OECD's core economic functions, the more likely OECD recommendations are to reflect the dominant economic paradigm; the more an area involves interaction between the OECD Economics Department and national economic ministries, the more likely it is to reflect neo-liberal policy prescriptions. Conversely, the more remote an area is from core OECD economic functions, and the more likely it is to involve collaboration between DELSA and national social policy ministries, the more open it may be to alternative discourses. There seems, however, to be an hierarchy of priorities within the OECD, as well as in its member states, in which economic imperatives for the most part outweigh those represented by other portfolios. The latter may have room to differentiate themselves from the main economic message, but are constrained to frame alternatives in ways that contribute to, rather than contradict, the dominant economic paradigm.

\section{Acknowledgement}

We thank two anonymous reviewers and the journal editors for helpful comments on an earlier draft. 


\section{References}

Armingeon, K. (2004), 'The OECD and national welfare state development', in K. Armingeon and M. Beyeler (eds), The OECD and European Welfare States, London: Edward Elgar.

Armingeon, L. and M. Beyeler (eds) (2004), The OECD and European Welfare States, London: Edward Elgar.

Bajoni, I., E. Berenzi and E. Neuman (2007), Final Report - Hungarian Education, Orientation 1, Knowledge and Policy in education and health, research report, December.

Barnett, M.N. and M. Finnemore (1999), 'The politics, power and pathology of international organizations', International Organization 53(4): 699-732.

Barroso, J., L. Carvalho, M. Fontoura, N. Afonso and E. Afonso (2007), Report - Policy Learning Mechanisms and the Morphology of Knowledge Field Research in Portugal - Education Sector, Orientation 1, Knowledge and Policy in education and health, research report, December.

Brenner, N. (2004), New State Spaces: Urban Governance and the Rescaling of Statehood, New York: Oxford University Press.

Casey, B. (2004), 'The OECD jobs strategy and the European employment strategy: two views of the labour market and of the welfare state', European Journal of Industrial Relations 10(3): 329-352.

Cox, R.W. (1987), Production, Power and World Order: Social Forces in the Making of History. New York: Columbia University Press.

— (2005), 'Global Perestroika', in R. Wilkinson (ed.), The Global Governance Reader, New York: Routledge, pp. 140-155.

Craig, D. and D. Porter (2004), 'The third way and the third world: poverty reduction and social inclusion strategies in the rise of "inclusive" liberalism', Review of International Political Economy 12: 387-423.

Deacon, B., M. Hulse and P. Stubbs (1997), Global Social Policy: International Organizations and the Future of the Welfare State, London: Sage.

Delvaux, B., C. Mangez, E. Mangez and C. Maroy (2007), Final Report-Belgian Education, Orientation 1 , Knowledge and Policy in education and health, research report, December.

Djelic, M.-L. and K. Sahlin-Andersson (2006a), 'A world of governance: the rise of transnational regulation', in M.-L. Djelic and K. Sahlin-Andersson (eds), Transnational Governance: Institutional Dynamics of Regulation, New York: Cambridge University Press, pp. 1-28.

- (2006b), 'Institutional dynamics in a reordering world', Transnational Governance: Institutional Dynamics of Regulation, New York: Cambridge University Press, pp. 375-397.

Dostal, J.M. (2004), 'Campaigning on expertise: how the OECD framed EU welfare and labour market policies - and why success could trigger failure', Journal of European Public Policy 11(3): 440-460.

Finnemore, M. (1996), 'Norms, culture and world politics: insights from sociology's institutionalism', International Organization 50(2): 325-347.

Grinvalds, H. (2008), 'The influence of OECD ideas: Danish Labour Market Policy from 1985-1993', in R. Mahon and S. McBride (eds), The OECD and Transnational Governance, Vancouver: University of British Columbia Press, pp. 188-204.

Haas, P. (1992), 'Introduction: epistemic communities and international policy coordination', International Organization 46: 1-35.

Hall, P.A. (1993), 'Policy paradigms, social learning, and the state: the case of economic policymaking in Britain', Comparative Politics 25(4): 275-296.

Jacobsson, B. (2006), 'Regulated regulators: global trends of state transformation', Transnational Governance, 205-224.

Jacobsson, B. and G. Sundstrom (2007), Governing State Agencies. Transformations in the Swedish Administrative Model, Stockholm: Scores rapportserie.

James, O. and M. Lodge (2003), 'The limitations of "policy transfer" and "lesson drawing" for public policy research', Policy Studies Review 1: 179-193.

Jenson, J. (2007), 'Redesigning citizenship regimes after neoliberalism: ideas about social investment'. Presented at RC 19 Annual Meeting, Florence, September. 
Lodge, M. (2005), 'The importance of being modern: international benchmarking and national regulatory innovation', Journal of European Public Policy 12(4): 649-667.

McBride, S. and R. Williams (2001), 'Globalization, the restructuring of labour markets and policy convergence: The OECD “Jobs Strategy”', Global Social Policy 1(3): 281-309.

McCracken, P.W. (1977), 'Towards full employment and price stability: report to the OECD by a group of independent experts', Carnegie-Rochester Conference Series on Public Policy, Vol. 11, Paris: OECD.

Noaksson, N. and K. Jacobsson (2003), The Production of Ideas and Expert Knowledge in OECD: The OECD Jobs Strategy in contrast with the EU Employment Strategy, Stockholm: SCORE (Stockholm Centre for Organizational Research).

OECD (2006), Babies and Bosses, Paris.

Porter, T. and M. Webb (2008), 'Role of the OECD in the orchestration of global knowledge networks', in R. Mahon and S. McBride (eds), The OECD and Transnational Governance, Vancouver: University of British Columbia Press, pp. 43-59.

Sahlin-Andersson, K. (2000), National, International and Transnational Construction of New Public Management, SCORE working paper 2000-4, Stockholm: Stockholm Centre for Organisational Research, Stockholm University.

Salzman, J. and J.B. Terracino (2006), 'Labor rights, globalization and institutions: the role and influence of the Organization for Economic Cooperation and Development', in V.A. Leay and D. Warner (eds), Social Issues, Globalization and International Institutions: Labor Rights and the EU, ILO, OECD and WTO, Boston: Martinus Nijhoff.

Sawyer, M. (2004), 'The NAIRU, labour market "flexibility", and full employment', in J. Stanford and L.F. Vosko (eds), Challenging the Market: The Struggle to Regulate Work and Income, Montreal: McGill-Queens University Press.

Schäfer, A. (2006), 'A new form of governance? Comparing the open method of coordination to multilateral surveillance by the IMF and the OECD', Journal of European Public Policy 13(1): 70-88.

Sinclair, T.J. (2005), The New Masters of Capital: American Bond Rating Agencies and the Politics of Creditworthiness, Ithaca: Cornell University Press.

Sullivan, S. (1997), From War to Wealth: 50 Years of Innovation, Paris: OECD.

Webb, M. (2004), 'Defining the boundaries of legitimate state practices: norms, transnational actors and the OECD's project on harmful tax competition', Review of International Political Economy 11(4): 787-827.

Williams, R. (2008), 'The role of the OECD in liberalising foreign investment: lessons from the MAI?', in R. Mahon and S. McBride (eds), The OECD and Transnational Governance, Vancouver: University of British Columbia Press, pp. 117-133.

Wolfe, R. (2008), 'From reconstructing Europe to constructing globalization: the OECD in historical perspective', in R. Mahon and S. McBride (eds), The OECD and Transnational Governance, Vancouver: University of British Columbia Press, pp. 25-42. 